\title{
COSMOGENIC NUCLIDES IN ICE SHEETS
}

\section{DEVENDRA LAL}

Scripps Institution of Oceanography, Geological Research Division, La Jolla, California 92093-0220 USA

and

\section{A. J. T. JULL}

NSF-Arizona Accelerator Facility for Radioisotope Analysis, The University of Arizona, Tucson Arizona 85721 USA

\begin{abstract}
We discuss the nature of the twofold record of cosmogenic nuclides in ice sheets, of nuclei produced in the atmosphere, and of nuclei produced in situ due to interactions of cosmic-ray particles with oxygen nuclei in ice. We show that a wealth of geophysical information, in principle, can be derived from a suitable combination of nuclides in ice deposited at different latitudes. Such knowledge includes temporal changes in the cosmic-ray flux, in the geomagnetic field and in climate. The rate of deposition of cosmogenic atmospheric nuclei in ice depends on the global cosmic-ray flux and a host of climatic factors. The global cosmic-ray flux, in turn, depends on the level of solar activity, and of the geomagnetic dipole field. Thus, the task of deconvolution of the record of cosmogenic nuclides is difficult, but can be facilitated by considering the recently discovered record of in-situ-produced cosmogenic ${ }^{14} \mathrm{C}$, whose production rate at high latitudes is independent of the geomagnetic dipole field (Lal 1992b). We also present a brief review of work done to date and new prospects for deciphering geophysical records using ice sheets.
\end{abstract}

\section{INTRODUCTION}

Seven long-lived cosmogenic nuclides with half-lives exceeding ten years, ${ }^{3} \mathrm{H},{ }^{32} \mathrm{Si},{ }^{14} \mathrm{C},{ }^{36} \mathrm{Cl},{ }^{26} \mathrm{Al}$, ${ }^{10} \mathrm{Be}$ and ${ }^{81} \mathrm{Kr}$, have been studied in polar ice (Coachman, Enns \& Scholander 1958; Lal \& Peters 1967; Aegerter et al. 1969; Fireman \& Norris 1982; Elmore et al. 1987; Beer et al. 1983; Nijampurkar, Bhandari \& Puri 1984; Oeschger 1985; Stauffer 1989; Craig et al. 1990). These investigations have focused on changes in historic/prehistoric cosmic-ray flux and terrestrial climate, and on ages of ice deposits. In this paper, we discuss applications of these nuclides for the study of prehistoric changes in cosmic-ray flux, due either to variations in the Earth's geomagnetic field or to a nearby supernova event. Thus, for this study, we do not consider the relatively short-lived nuclides, ${ }^{3} \mathrm{H}$ and ${ }^{32} \mathrm{Si}$. We also exclude ${ }^{36} \mathrm{Cl}$; the relation of its concentration to meteorological factors makes it difficult to correlate the record with changes in cosmic-ray flux (Elmore et al. 1987).

The remaining nuclides, ${ }^{10} \mathrm{Be},{ }^{14} \mathrm{C},{ }^{26} \mathrm{Al}$ and ${ }^{81} \mathrm{Kr}$, with different half-lives, chemistry and production mechanisms, promise to be helpful in unravelling the nature of changes in the prehistoric cosmicray flux. Several cosmic-ray events, with rapid and slow changes have been identified in the ${ }^{14} \mathrm{C}$ record in tree rings, and in the ${ }^{10} \mathrm{Be}$ record in polar ice (Suess 1970; Kocharov 1990; Stuiver et al. 1991; Raisbeck et al. 1981, 1990, 1992; Raisbeck \& Yiou 1988; Beer et al. 1983, 1984, 1988). However, because similar time scales are involved in climatic changes, and because these climatic changes produce significant modulations in cosmogenic records (Lal 1985, 1987), it is not always possible to assert what fraction of the amplitude modulation in the record is due to change in the cosmic-ray flux.

Two prominent records are seen in the records mentioned above:

1. The 200-year periodicity and a slow variation on time scales of $5-10 \mathrm{ka}$ in ${ }^{14} \mathrm{C} /{ }^{12} \mathrm{C}$ ratios in tree rings

2. Spikes in ${ }^{10} \mathrm{Be}$ concentrations in polar ice, particularly at $\sim 35$ and $60 \mathrm{ka}$ BP. 
In this paper, we discuss causative mechanisms for variations in cosmogenic nuclide abundances. No consensus exists at present for causes of the prominent changes; extreme views are often presented. For example, in the case of ${ }^{14} \mathrm{C}$ variations, one group advocates that these fluctuations are due entirely to changes in the cosmic-ray flux, primarily because of changes in solar activity and in the geomagnetic field (Stuiver et al. 1991; Damon \& Sonett 1991). Another view attributes the fluctuations to a major climatic component (Lal 1985). In the case of the ${ }^{10} \mathrm{Be}$ record in ice sheets, concentration enhancements have been attributed to an increased cosmic-ray flux due to interstellar shock waves (Sonett, Morfill \& Jokipii 1987) and to nearby supernova explosions (Kocharov \& Konstantinov 1983; Kocharov 1990). Lal (1987) and Lal and Lingenfelter (1991) discuss recent controversies.

\section{INTERPRETATION OF THE COSMOGENIC RECORD}

The cosmic-ray-flux incident on the Earth is more variable in time than that in interstellar space. First, the solar plasma modulates the incoming cosmic-ray flux in an energy-dependent fashion (Garcia-Munoz, Mason \& Simpson 1977; Castagnoli \& Lal 1980). The magnitude of production depends on solar activity, which displays a range of characteristic periods, e.g., ca. 11, 80, 200 and $2000 \mathrm{yr}$ (Damon \& Sonett 1991). The geomagnetic field of the Earth, principally the dipole field, determines the cosmic-ray flux at different geomagnetic latitudes. The field (dipole?) appears to have undergone dramatic changes in the past $80 \mathrm{ka}$ (cf. Mazaud et al. 1991). The production rates of ${ }^{14} \mathrm{C}$ and ${ }^{10} \mathrm{Be}$ for different levels of solar activity and geomagnetic field intensities can be calculated fairly accurately (Lal 1988, 1992a, b).

Prior to the availability of the record of long-lived cosmogenic radionuclides in ice sheets, the most useful accessible long time series of a cosmogenic radionuclide was that of ${ }^{14} \mathrm{C}$ in tree rings. A time series now exists to $\sim 10^{5} \mathrm{BP}$ for ${ }^{10} \mathrm{Be}$ (Raisbeck et al. 1990). Beer et al. (1988) compared the ${ }^{14} \mathrm{C}$ time series in tree rings with the ${ }^{10} \mathrm{Be}$ time series in ice. They concluded that both series show similar short-term trends; the 200 -yr cycle in the ${ }^{14} \mathrm{C}$ record is also clearly seen in the ${ }^{10} \mathrm{Be}$ record, but the geomagnetic dipole field variation seen prominently in the ${ }^{14} \mathrm{C}$ record is not apparent in the ${ }^{10} \mathrm{Be}$ sequence. In a recent high-resolution study of ${ }^{10} \mathrm{Be}$ concentration in a south Greenland ice core from Dye 3, Beer et al. (1990) found a fairly large amplitude variation with a period of $11 \mathrm{yr}$.

Pre-Holocene ${ }^{10} \mathrm{Be}$ concentrations in polar ice are higher than those during the Holocene. The principal cause of this variation is believed to be lower precipitation rates during cooler periods, evidenced by the good inverse correlation between ${ }^{10} \mathrm{Be}$ concentration and $\delta^{18} \mathrm{O}$ values of ice (Raisbeck \& Yiou 1988). In the pre-Holocene ${ }^{10} \mathrm{Be}$ time series in Vostok ice, two prominent peaks are present at $\sim 35$ and $60 \mathrm{ka} \mathrm{BP}$, which are not correlated with $\delta^{18} \mathrm{O}$ (see Sonett 1992).

Explanations have been offered for observed oscillations and excursions in the time series of ${ }^{14} \mathrm{C}$ in tree rings and of ${ }^{10} \mathrm{Be}$ in ice sheets. Bard et al. (1990) extended the ${ }^{14} \mathrm{C} /{ }^{12} \mathrm{C}$ time series back to $30 \mathrm{ka} \mathrm{BP}$, and observed larger amplitude variability than in the Holocene period. For ${ }^{14} \mathrm{C}$, whose principal reservoir is the ocean, it may be that climatic changes, along with corresponding changes in ocean chemistry and in parameters governing atmosphere-ocean ${ }^{14} \mathrm{C}$ exchange, would strongly modulate atmospheric ${ }^{14} \mathrm{C} /{ }^{12} \mathrm{C}$ ratios. Theoretical considerations for the Holocene (Lal 1985) seem to support this. However, as mentioned above, there appears to be a general consensus that variations in ${ }^{14} \mathrm{C} /{ }^{12} \mathrm{C}$ ratios are related primarily to changes in cosmic-ray flux, due either to variation in the geomagnetic dipole field ( $c f$. Damon \& Sonett 1991; Stuiver et al. 1991; Bard et al. 1990), or in solar activity (cf. Damon \& Sonett 1991; Stuiver et al. 1991).

A question exists regarding the cause of enhanced ${ }^{14} \mathrm{C} /{ }^{12} \mathrm{C}$ events observed in corals, and the high ${ }^{10} \mathrm{Be}$ concentration in ice samples in the $(10-150) \times 10^{3} \mathrm{BP}$ epoch. Raisbeck et al. (1992) recently 
considered this question in detail, and concluded that the only likely reason is that ${ }^{14} \mathrm{C}$ and ${ }^{10} \mathrm{Be}$ were produced in ratios much higher than those due to the galactic cosmic-ray flux. The mechanism of this production is not yet clear; solar flare particles, supernova shock waves or $\gamma$-rays are suspected (Raisbeck et al. 1992; see also Sonett 1992).

Direct production of the radionuclides, ${ }^{3} \mathrm{H},{ }^{14} \mathrm{C},{ }^{10} \mathrm{Be}$, in ice is expected from nuclear spallation of oxygen in ice. Lal, Nishiizumi and Arnold (1987) estimated their production rates; they showed that in-situ ${ }^{14} \mathrm{C}$ could be detected easily, but the expected concentration of in-situ ${ }^{10} \mathrm{Be}$ is much lower than that added to ice from the removal of atmospheric ${ }^{10} \mathrm{Be}$, by one order of magnitude.

Thus, the application of $i n-s i t u{ }^{10} \mathrm{Be}$ to ice sheets should be considered only in special cases. For example, if the rate of ice accumulation decreases rapidly, a higher in-situ production rate of ${ }^{10} \mathrm{Be}$ would result. In theory, then, changes in ice accumulation rates can possibly be delineated using in-situ ${ }^{10} \mathrm{Be}$.

In-situ production rates of ${ }^{14} \mathrm{C}$ in surface polar ice are estimated to be $15,38,84,164$ and $480{ }^{14} \mathrm{C}$ atoms ( $(\mathrm{g} \text { ice } \cdot \mathrm{yr})^{-1}$, at altitudes of 0 (sea level), 1, 2, 3 and $5 \mathrm{~km}$, respectively (Lal et al. 1990). Recent data have shown that ${ }^{14} \mathrm{C}$ accumulated during ablation agrees well with these expectations, yielding model ablation ages for Allan Hills and Cul-de-Sac ablation ice consistent with those measured using the stake method (Lal et al. 1990). Measurements in progress also establish high retention of $i$-situ ${ }^{14} \mathrm{C}$ in accumulation ice (Jull \& Lal, ms. in preparation).

Lal, Nishiizumi and Arnold (1987) and Lal and Jull (1990) have discussed expected concentrations of ${ }^{14} \mathrm{C}$ in accumulation and ablation ice. For a constant accumulation rate, the peak ${ }^{14} \mathrm{C}$ concentration in the ice, $\mathrm{C}_{\mathrm{m}}$ is

$$
C_{m}=0.176 \frac{P_{0}}{S}
$$

where $\mathrm{s}$ is the accumulation rate, and $\mathrm{P}_{\mathrm{o}}$ is the production rate of ${ }^{14} \mathrm{C}$ in ice at the surface. Thus, the resulting concentration of ${ }^{14} \mathrm{C}$ produced in situ is inversely proportional to the ice accumulation rate, $\mathrm{s}$, and proportional to the ${ }^{14} \mathrm{C}$ surface production rate, $\mathrm{P}_{\mathrm{o}}$. A similar effect is mimicked by atmospheric ${ }^{10} \mathrm{Be}$ deposited in ice by wet precipitation.

Any changes in the dipole moment of the Earth's geomagnetic field would not change the in-situ production rate of ${ }^{14} \mathrm{C}$ or ${ }^{10} \mathrm{Be}$ in ice in the polar regions. But the concentrations of atmospheric ${ }^{14} \mathrm{C}$ and ${ }^{10} \mathrm{Be}$ would respond to changes in the Earth's dipole field.

In light of the foregoing, we recognize three principal records (time series) of long-lived cosmogenic nuclides in ice, which contain clues to temporal variations in geophysical parameters:

1. Atmospheric cosmogenic nuclides present in air trapped during firn-ice transition, namely ${ }^{3} \mathrm{He},{ }^{14} \mathrm{C}$ and ${ }^{81} \mathrm{Kr}$

2. Atmospheric cosmogenic nuclides deposited by wet precipitation, namely ${ }^{3} \mathrm{H},{ }^{10} \mathrm{Be},{ }^{26} \mathrm{Al}$ and ${ }^{36} \mathrm{Cl}$

3. In-situ cosmogenic nuclides produced by nuclear spallation of oxygen in ice, namely ${ }^{3} \mathrm{H}$, ${ }^{10} \mathrm{Be}$ and ${ }^{14} \mathrm{C}$.

\section{Nuclides in Category (1)}

Temporal changes in the relative proportions of ${ }^{3} \mathrm{He}:{ }^{4} \mathrm{He}: \mathrm{N}_{2}$ in trapped air in ice are expected due to changes in: 1) temperature at the base of the exosphere; 2) solar wind accretion of ${ }^{3} \mathrm{He}$; 3) changes in the cosmic-ray production rates of ${ }^{3} \mathrm{H}$ and ${ }^{3} \mathrm{He}$ in the atmosphere. In principle, then, much useful information can be obtained from such studies. During strong polar blackout events 
caused by large solar flares, or during brief periods of low or zero geomagnetic field intensity, appreciable amounts of solar ${ }^{3} \mathrm{He}$ (with ${ }^{3} \mathrm{He} /{ }^{4} \mathrm{He}$ ratios $\sim 200$ times the atmospheric value), may be accreted.

The nuclides, ${ }^{14} \mathrm{C}$ and ${ }^{81} \mathrm{Kr}$, can provide a record of atmospheric ${ }^{14} \mathrm{C} /{ }^{12} \mathrm{C}$ and ${ }^{81} \mathrm{Kr} / \mathrm{Kr}$ ratios, which depend on several parameters. The relatively shorter-lived ${ }^{14} \mathrm{C}$ provides information regarding average cosmic-ray flux over a period of $c a .10^{4}$ years prior to ice formation. This record will reflect changes in the geomagnetic field and any changes in the cosmic-ray flux due to a nearby supernova; cosmic-ray-flux modulations due to solar activity variations will largely be averaged out. On the other hand, the nuclide, ${ }^{81} \mathrm{Kr}$ (produced in thermal neutron capture by ${ }^{80} \mathrm{Kr}$ ), will average out changes in solar activity and presumably the geomagnetic field, judging from variations in the geomagnetic field intensity during the past $80 \mathrm{ka}$ (Mazaud et al. 1991). Any temporal deviations in ${ }^{81} \mathrm{Kr} / \mathrm{Kr}$ ratios would then be due primarily to a nearby supernova event or other event that changes the cosmic-ray flux in the vicinity of the solar system (Sonett, Morfill \& Jokipii 1987; Kocharov \& Konstantinov 1983; Kocharov 1990; see also Sonett 1992).

Nuclides in Categories (2) and (3)

We have briefly outlined the observed records of ${ }^{36} \mathrm{Cl}$ and ${ }^{10} \mathrm{Be}$ in ice; concentrations derive primarily from their removal from atmospheric inventories by wet precipitation. The nuclides, ${ }^{36} \mathrm{Cl}$ (and ${ }^{26} \mathrm{Al}$ ), cannot be produced significantly in situ in ice.

In Table 1, we show the response of different nuclides to changes in geophysical and astrophysical parameters for nuclides in categories (2) and (3). Among the nuclides considered, ${ }^{26} \mathrm{Al}$ is the only one whose concentration in ice would be sensitive to temporal changes in the flux of cosmic dust.

TABLE 1. Comments on the response of the record of cosmic-ray nuclides in ice sheets in polar/temperate latitudes to changes in cosmic-ray flux arising from three different mechanisms

\begin{tabular}{|c|c|c|c|c|c|c|c|c|}
\hline \multirow{3}{*}{$\begin{array}{l}\text { Cause of } \\
\text { change }\end{array}$} & \multicolumn{4}{|c|}{$\underline{I n \text {-situ production in ice sheets }}$} & \multicolumn{4}{|c|}{ Depositional flux } \\
\hline & \multicolumn{2}{|c|}{ Polar regions } & \multicolumn{2}{|c|}{ Temperate latitudes } & \multicolumn{2}{|c|}{ Polar regions } & \multicolumn{2}{|c|}{ Temperate latitudes } \\
\hline & ${ }^{14} \mathrm{C}$ & ${ }^{10} \mathrm{Be}$ & ${ }^{14} \mathrm{C}$ & ${ }^{10} \mathrm{Be}$ & ${ }^{10} \mathrm{Be}$ & ${ }^{26} \mathrm{Al}$ & ${ }^{10} \mathrm{Be}$ & ${ }^{26} \mathrm{Al}$ \\
\hline $\begin{array}{l}\text { Geomagnetic } \\
\text { dipole field }\end{array}$ & $x$ & $x$ & $\sqrt{ }$ & $\sqrt{ }$ & $\sqrt{ }(w)$ & $\sqrt{ }(w)$ & $\sqrt{ }(w)$ & $\sqrt{ }(w)$ \\
\hline Solar activity & $\sqrt{ }$ & $\sqrt{ }$ & $x$ & $x$ & $\sqrt{ }(w)$ & $\sqrt{ }(w)$ & $x$ & $x$ \\
\hline $\begin{array}{l}\text { Nearby } \\
\text { supernova }\end{array}$ & $\sqrt{ }$ & $\sqrt{ }$ & $\sqrt{ }(w)$ & $\sqrt{ }(w)$ & $\sqrt{ }$ & $\sqrt{ }$ & $\sqrt{ }(w)$ & $\sqrt{ }(w)$ \\
\hline
\end{tabular}

$\checkmark=$ a good signal is expected

$(w)=$ a weak or a weaker signal

$x=$ no signal is expected

It is important to note that some cosmogenic records are of integral type, whereas others are of differential type. Records of trapped ${ }^{14} \mathrm{C}$ and ${ }^{81} \mathrm{Kr}$ are integral records, whereas the record of in-situproduced ${ }^{14} \mathrm{C}$ is a differential record; the depositional flux of ${ }^{10} \mathrm{Be}$ also yields a differential record. Integral records are low-pass records; higher frequencies are attenuated more severely. For example, assume that the observed excursions in ${ }^{10} \mathrm{Be}$ concentrations at 35 and $60 \mathrm{ka} \mathrm{BP}$ are due to nearby supernova explosions. If these events led to cosmic-ray-intensity increases lasting for effective average periods of $\sim 1 \mathrm{ka}$, the average ${ }^{81} \mathrm{Kr} / \mathrm{Kr}$ ratios in $0-30 \mathrm{ka}$ ice may only show a small increase of $\sim 0.7 \%$ for a $100 \%$ increase in cosmic-ray flux. The attenuation would be much less in the case of atmospheric trapped ${ }^{14} \mathrm{C}$. 


\section{CONCLUSIONS}

We have discussed three principal records of cosmogenic nuclides in ice sheets: atmospheric nuclides trapped with air occluded in ice, atmospheric nuclides deposited by wet precipitation, and nuclides produced in situ in ice by spallation of oxygen in ice. Records of long-lived nuclides are available in each case. Deconvolution of the records to delineate temporal changes in the following geophysical parameters: 1) cosmic-ray intensity in the heliosphere; 2) geomagnetic dipole field intensity; and 3) solar activity is complex, however. Climatic changes produce appreciable perturbations in these records. We have shown that a careful study of the three records can delineate the cause of temporal variation in each.

A case in point concerns the observed sharp changes in the concentrations of ${ }^{10} \mathrm{Be}$ in Vostok ice at $\sim 35$ and $60 \mathrm{ka}$ BP. Do these constitute a record of nearby supernova explosions? If there was an appreciable change in the cosmic-ray flux in the heliosphere due to a nearby supernova, one would expect an increase in the in-situ ${ }^{14} \mathrm{C}$ production rate also, as well as in the ratio of ${ }^{14} \mathrm{C} /{ }^{12} \mathrm{C}$ in the trapped air. However, resultant changes in ${ }^{10} \mathrm{Be}$ concentration would be much larger, because the latter is an integral record.

Therefore, we hope that the current debate regarding causes for the observed oscillations and excursions in the time series of cosmogenic nuclides can be addressed from a combined study of cosmogenic records in ice and in tree rings. Studies in ice sheets in temperate latitudes would be of particular significance in describing temporal changes in the geomagnetic dipole field. It would be useful to include studies of cosmogenic ${ }^{32} \mathrm{Si}$ in ice deposited during 50-300 $\mathrm{BP}$ in investigating climatic effects during its removal from the atmosphere, expected to be similar to that for ${ }^{10} \mathrm{Be}$. However, in the case of ${ }^{10} \mathrm{Be}$, appreciable amounts can be redeposited by recirculation of atmospheric dust; this is not expected to be important in the case of ${ }^{32} \mathrm{Si}$.

\section{ACKNOWLEDGEMENTS}

We are grateful to Drs. D. J. Donahue, G. Raisbeck and F. Yiou for discussions. This work was supported in part by NSF Grant DPP-9017827, to D. Lal.

\section{REFERENCES}

Aegerter, S., Oeschger, H., Renaud, A. and Schumacher, E. 1969 Studies based on the tritium content of the samples. In Renaud, A., ed., Etudes Physiques et Chimiques sur la Glace de l'Indlandis du Groenland 1959 EGIG 1957-1960 5(3). Copenhagen, Bianco Lunos Bogtrykker A/S: 76-88.

Bard, E., Hamelin, B., Fairbanks, R. G. and Zindler, A. 1990 Calibration of the ${ }^{14} \mathrm{C}$ timescale over the past 30,000 years using mass spectrometric U-Th ages from Barbados corals. Nature 345: 405-410.

Beer, J., Andrée, M., Oeschger, H., Siegenthaler, U., Bonani, G., Hofmann, H., Morenzoni, E., Nesi, M., Suter, M., Wölfli, W., Finkel, R. and Langway, C. C., Jr. 1984 The Camp Century ${ }^{10} \mathrm{Be}$ record: Implications for long-term variations of the geomagnetic dipole moment. In Wölfli, W., Polach, H. A. and Anderson, H. H., eds., Proceedings of the 3rd International Symposium on Accelerator Mass Spectrometry. Nuclear Instruments and Methods B5: 380-384.

Beer, J., Andrée, M., Oeschger, H., Stauffer, B., Balzer,
R., Bonani, G., Stoller, M., Suter, M., Wölfli, W. and Finkel, R. C. 1983 Temporal ${ }^{10} \mathrm{Be}$ variations in ice. In Stuiver, M. and Kra, R. S., eds., Proceedings of the 11th International ${ }^{14} \mathrm{C}$ Conference. Radiocarbon 25 (2): 269-278.

Beer, J., Blinov, A., Bonani, G., Finkel, R. C., Hofmann, H. J., Lehmann, B., Oeschger, H., Sigg, A., Schwander, J., Staffenbach, T., Stauffer, B., Suter, M. and Wölfli, W. 1990 Use of ${ }^{10} \mathrm{Be}$ in polar ice to trace the 11-year cycle of solar activity. Nature 347: 164-166.

Beer, J., Siegenthaler, U., Bonani, G., Finkel, R. C., Oeschger, H., Suter, M. and Wölfli, W. 1988 Information on past solar activity and geomagnetism from ${ }^{10} \mathrm{Be}$ in the Camp Century ice core. Nature 331: 675-679.

Castagnoli, G. and Lal, D. 1980 Solar modulation effects in terrestrial production of carbon-14. In Stuiver, M. and Kra, R. S., eds., Proceedings of the 10th International ${ }^{14} \mathrm{C}$ Conference. Radiocarbon 22 
(2): 133-158.

Coachman, L. K., Enns, T. and Scholander, P. F. 1958 Gas loss from a temperate glacier. Tellus 10: 493-495.

Craig, H., Cerling, T. E., Willis, R. D., Davis, W. A., Joyner, C. and Thonnard, N. 1990 Krypton 81 in Antarctic Ice: First measurement of a Krypton age on ancient ice. EOS 71: 1825.

Damon, P. E. and Sonett, C. P. 1991 Solar and terrestrial components of the atmospheric ${ }^{14} \mathrm{C}$ variation spectrum. In Sonett, C. P., Giampapa, N. S. and Matthews, M. S., eds., The Sun in Time. Tucson, The University of Arizona Press: 360-388.

Elmore, D., Conrad, N. J., Kubik, P. W. and Gove, H. E. $1987{ }^{36} \mathrm{Cl}$ and ${ }^{10} \mathrm{Be}$ profiles in Greenland ice: dating and production rate variations. In Gove, H. E., Litherland, A. E. and Elmore, D., eds., Proceedings of the 4th International Symposium on Accelerator Mass Spectrometry. Nuclear Instruments and Methods B29: 207-210.

Fireman, E. L. and Norris, T. 1981 Carbon-14 ages of Allan Hills meteorites and ice. Proceedings of the Lunar and Planetary Science Conference 12: 10191025.

Garcia-Munoz, M., Mason, M. and Simpson, J. 1977 New aspects of the cosmic-ray modulation in 19741975 near-solar minimum. Astrophysical Journal 231: 263-268.

Kocharov, G. E. 1990 Investigation of astrophysical and geophysical problems by AMS: Successes achieved and prospects. In Yiou, F. and Raisbeck, G. M., eds., Proceedings of the 5th International Conference on Accelerator Mass Spectrometry. Nuclear Instruments and Methods B52: 583-587.

Kocharov, G. E. and Konstantinov, A. N. 1983 Cosmogenic nuclide ${ }^{10} \mathrm{Be}$ abundance in the ice cores and the time variation of cosmic rays. In Conference Papers, 18th International Cosmic Ray Conference, Bangalore, India. OG 2, OG 7-1: 333-336.

Lal, D. 1985 Carbon cycle variations during the past 50,000 years: Atmospheric ${ }^{14} \mathrm{C} /{ }^{12} \mathrm{C}$ ratio as an isotopic indicator. In Sundquist, E. T. and Broecker, W. S., eds., American Geophysical Union Monograph 32: 221-233.

$1987{ }^{10} \mathrm{Be}$ in polar ice: Data reflect changes in cosmic ray flux or polar meteorology? Geophysical Research Letters. 14(8): 785-788.

1988 Theoretically expected variations in the terrestrial cosmic-ray productions rates of isotopes. In Castagnoli, G. C., ed., Solar Terrestrial Relationships and the Earth Environment in the Last Millennia. Amsterdam, North Holland: 216-233.

1992a Expected secular variations in the global terrestrial production rate of radiocarbon. In Bard, E. and Broecker, W. S., eds., The Last Deglaciation: Absolute and Radiocarbon Chronologies. NATO ASI Series I-2. Berlin Heidelberg, Springer-Verlag: 113126.

1992b Cosmogenic in situ radiocarbon on the
Earth. In Taylor, R. E., Long, A. and Kra, R. S., eds., Radiocarbon After Four Decades: An Interdisciplinary Perspective. New York, Springer-Verlag: 146162.

Lal, D. and Jull, A. J. T. 1990 On determining ice accumulation rates in the past 40,000 years using in situ cosmogenic ${ }^{14} \mathrm{C}$. Geophysical Research Letters 17(9): 1303-1306.

Lal, D., Jull, A. J. T., Donahue, D. J., Burtner, D. and Nishiizumi, K. 1990 Polar ice ablation rates measured in situ cosmogenic ${ }^{14} \mathrm{C}$. Nature 346: 350-352.

Lal, D. and Lingenfelter, R. E. 1991 History of the sun during the past $4.5 \mathrm{Gyr}$ as revealed by studies of energetic solar particles recorded in extraterrestrial and terrestrial samples. In Sonett, C. P., Giampapa, M. S. and Matthews, M. S., eds., The Sun in Time. Tucson, The University of Arizona Press: 221-231.

Lal, D., Nishiizumi, K. and Arnold, J. R. 1987 In situ cosmogenic ${ }^{3} \mathrm{H},{ }^{14} \mathrm{C}$ and ${ }^{10} \mathrm{Be}$ for determining the net accumulation and ablation rates of ice sheets. Journal of Geophysical Research 92: 4947-4952.

Lal, D. and Peters, B. 1967 Cosmic-ray produced radioactivity on the Earth. In Sitte, K., ed., Encyclopedia of Physics 46/2. Amsterdam, North Holland: 551-612.

Mazaud, A., Laj, C., Bard, E., Arnold, M. and Tric, E. 1991 Geomagnetic field control of ${ }^{14} \mathrm{C}$ production over the last $80 \mathrm{ky}$ : Implications for the radiocarbon time-scale. Geophysical Research Letters 18: 18851888.

Nijampurkar, N., Bhandari, N. and Puri, V. M. K. 1984 Ice dynamics and accumulation rates on ChangmeKhangpu glacier, Sikkim. In Isotope Hydrology 1983. Vienna, IAEA: 31-41.

Oeschger, H. 1985 The contribution of ice core studies to the understanding of environmental processes. In Langway, C. C., Jr., Oeschger, H. and Dansgaard, W., eds., Greenland Ice Core: Geophysics, Geochemistry and the Environment. American Geophysical Union Monograph 33: 9-17.

Raisbeck, G. M. and Yiou, F. $1988{ }^{10} \mathrm{Be}$ as a proxy indicator of variations in solar activity and geomagnetic field intensity during the last 10,000 years. In Stephenson, F. R. and Wolfendale, A. W., eds., Secular Solar and Geomagnetic Variations in the Last 10,000 Years. Dordrecht, The Netherlands, Kluwer Academic Publishers: 287-296.

Raisbeck, G. M., Yiou, F., Fruneau, M., Loiseaux, J. M., Lieuvin, M., Ravel, J. C. and Lorius, C. 1981 Cosmogenic ${ }^{10} \mathrm{Be}$ concentrations in Antarctic ice during the past 30,000 years. Nature 292: 825-826.

Raisbeck, G. M., Yiou, F., Jouzel, J. and Petit, J. R. $1990{ }^{10} \mathrm{Be}$ and $\delta^{2} \mathrm{H}$ in polar ice cores as a probe of the solar variability's influence on climate. Philosophical Transactions of the Royal Society of London A330: 463-470.

Raisbeck, G. M., Yiou, F., Jouzel, J., Petit, J. R., Barkov, N. I. and Bard, E. $1992{ }^{10} \mathrm{Be}$ deposition at 
Vostok, Antarctica during the last 50,000 years and its relationship to possible cosmogenic production variations during this period. In Bard, E. and Broecker, W. S., eds., The Last Deglaciation: Absolute and Radiocarbon Chronologies. NATO ASI Series I-2. Berlin Heidelberg, Springer-Verlag: 127-139.

Sonett, C. P., Morfill, G. E. and Jokipii, J. R. 1987 Interstellar shock waves and ${ }^{10} \mathrm{Be}$ from ice cores. Nature 330: 458-460.

Stauffer, B. R. 1989 Dating of ice by radioactive isotopes. In Oeschger, H. and Langway, C.C., Jr., eds., The Environment Record in Glaciers and Ice Sheets. New York, John Wiley \& Sons: 123-140.

Stuiver, M., Braziunas, T. F., Becker, B. and Kromer, B. 1991 Climatic, solar, oceanic and geomagnetic influences on Late-Glacial and Holocene atmospheric ${ }^{14} \mathrm{C} /{ }^{12} \mathrm{C}$ change. Quaternary Research 35: 1-24.

Suess, H. E. 1970 Bristlecone-pine calibration of the radiocarbon time-scale $5200 \mathrm{BC}$ to the present. In Olsson, I. U., ed., Radiocarbon Variations and Absolute Chronology. Proceedings of the 12th Nobel Symposium. New York, John Wiley \& Sons: 595-612. 